\title{
Teachers' Perceptions about the Impact of Moodle in the Educational Field Considering Data Science
}

\author{
Ricardo-Adán Salas-Rueda ${ }^{1^{*}}$ \\ (iD) 0000-0002-4188-4610 SC 57190010006
}

\section{Ana-Libia Eslava-Cervantes 1 \\ (i) 0000-0002-7420-3412}

\author{
Estefanía Prieto-Larios ${ }^{2}$ \\ (D) 0000-0002-8140-2778 \\ ${ }^{1}$ Institute of Applied Sciences and Technology, National Autonomous University of Mexico, MEXICO \\ ${ }^{2}$ National Autonomous University of Mexico, MEXICO \\ *Corresponding author: ricardoadansalasrueda@hotmail.com
}

Citation: Salas-Rueda, R.-A., Eslava-Cervantes, A.-L., \& Prieto-Larios, E. (2020). Teachers' Perceptions about the Impact of Moodle in the Educational Field Considering Data Science. Online Journal of Communication and Media Technologies, 10(4), e202023. https://doi.org/10.30935/ojcmt/8498

\section{ARTICLE INFO}

Received: 9 Jun 2020

Published: 27 Jul 2020

\begin{abstract}
Today, Learning Management Systems (LMS) such as Moodle facilitate the teaching-learning process, promote the organization of creative activities from anywhere and allow the active participation of the students before, during and after the face-to-face sessions. The objective of this quantitative research is to analyze the teachers' perceptions about the impact of Moodle in the educational field considering data science and machine learning. The independent variable is the use of Moodle during the organization of new school activities and the dependent variables are the performance of the activities inside and outside the classroom and the participation and communication during the educational process. The participants are 70 teachers from the National Autonomous University of Mexico (UNAM). The results of machine learning (linear regression) indicate that Moodle positively influences the participation and communication during the educational process. Likewise, this LMS positively influences the performance of the activities inside and outside the classroom. In particular, Moodle allows improving the educational field through the realization of the online exams and discussion forums, diffusion of the tasks and consultation of the contents at any time. Data science identifies 3 predictive models on the impact of Moodle in the educational field. In fact, the decision tree technique establishes the conditions on the use of this LMS considering the characteristics of the teachers (sex and maximum degree of study). The implications of this research allow affirming that teachers have the opportunity to create, organize and carry out various creative and active activities through this LMS. Finally, teachers can use Moodle to update the activities of the courses and build new educational spaces that allow the active role of the students during the learning process.
\end{abstract}

Keywords: Moodle, teaching, technology, data science, machine learning

\section{INTRODUCTION}

Educational institutions are using the Learning Management Systems (LMS) to facilitate the teachinglearning process from anywhere (Horvat et al., 2015; Salas-Rueda, 2020) and organize new school activities such as the realization of the online exams and discussion forums, diffusion of the tasks and consultation of the contents (Salas-Rueda, Salas-Rueda, \& Salas-Rueda, 2020; Shah \& Cheng, 2019; Then et al., 2016). For example, Moodle allows that students consult the resources and materials of the courses at home and office (Silva-Ordaz et al., 2016; Then et al., 2016).

Copyright (c) $\mathbf{2 0 2 0}$ by authors; licensee OJCMT. This article is an open access article distributed under the terms and conditions of the Creative Commons Attribution License (http://creativecommons.org/licenses/by/4.0/). 
Technological advances such as LMS, digital tools and web applications allow the active participation of the students before, during and after the face-to-face session (Dreamson et al., 2018; Kyzy, Ismailova, \& Dundar, 2018; Salas-Rueda, 2019). In particular, Moodle facilitates the organization and realization of the online exams inside and outside the classroom (Al-Azawei, Baiee, \& Mohammed, 2019; Jebari, Boussedra, \& Ettouhami, 2017; Shdiafat \& Obeidallah, 2019).

Even teachers can create new educational spaces through the use of the technology (Gutman, 2017; Jebari, Boussedra, \& Ettouhami, 2017; Limongelli et al., 2016; Salas-Rueda \& Lugo-García, 2019). For example, students have an active role during the teaching-learning process through the realization of the discussion forums in Moodle (Rehatschek, Holzl, \& Fladischer, 2011).

LMS have a fundamental role in the educational field because teachers organize the student-centered activities (González, Pintor-Chávez, \& Gómez-Zermeño, 2016; Romero-Díaz, Sola-Martínez, \& Trujillo-Torres, 2015; Veytia-Bucheli \& Leyva-Ortiz, 2016). In fact, Moodle facilitate the interaction and communication between the students during the realization of the distance courses (González, Pintor-Chávez, \& GómezZermeño, 2016; Romero-Díaz, Sola-Martínez, \& Trujillo-Torres, 2015; Vidrio-Talavera, Gómez-Zermeño, \& Zambrano-Izquierdo, 2015).

Even, LMS facilitate the dissemination of the audiovisual contents and consultation of the information of the courses at any time (Cobanoglu, 2018; Kotama, Saputra, \& Linawati, 2019; Tumbleson, 2016). The use of mobile devices in the educational field allows the consultation of the videos and carrying out of the activities in Moodle (Aikina \& Bolsunovskaya, 2020).

LMS such as Moodle are changing the interaction, communication and roles of teachers and students during the educational process (Islam, 2015; Mafuna \& Wadesango, 2016; Oskouei \& Kor, 2017). In fact, educational institutions are promoting the use of LMS in order to facilitate the active role of students. In particular, Moodle has a web interface that is easy to use and free.

Therefore, this quantitative research aims to analyze the teachers' perceptions about the impact of Moodle in the educational field considering data science and machine learning. The research questions are:

- How does the use of Moodle influence the participation and communication during the educational process?

- How does the use of Moodle influence the performance of the activities inside the classroom?

- How does the use of Moodle influence the performance of the activities outside the classroom?

\section{LEARNING MANAGEMENT SYSTEM}

The use of LMS in the educational field allows that teachers organize new school activities such as the realization of the online exams and discussion forums, review of the digital presentations and consultation of the course information at any time (Rehatschek, Holzl , \& Fladischer, 2011; Veytia-Bucheli \& Leyva-Ortiz, 2016; Vidrio-Talavera, Gómez-Zermeño, \& Zambrano-Izquierdo, 2015). In particular, Moodle improved the teachinglearning conditions in the courses of Engineering (Aikina \& Bolsunovskaya, 2020), Computer science (AlAzawei, Baiee, \& Mohammed, 2019), Information Systems Management (Jebari, Boussedra, \& Ettouhami, 2017), Mechatronics (Ferreira \& Cardoso, 2005), Management System (El-Seoud, Ahmad, \& El-Sofany, 2009), Computer Science (Vidrio-Talavera, Gómez-Zermeño, \& Zambrano-Izquierdo, 2015) and Education (VeytiaBucheli \& Leyva-Ortiz, 2016).

In the 21st century, teachers are creating new learning spaces by incorporating LMS in the school activities (Al-Azawei, Baiee, \& Mohammed, 2019; Kotama, Saputra, \& Linawati, 2019). For example, Moodle was used to improve the teaching-learning conditions through the use of the video games (Kotama, Saputra, \& Linawati, 2019).

Teachers can organize and realize creative activities in the LMS (Aikina \& Bolsunovskaya, 2020; Shdiafat \& Obeidallah, 2019; Veytia-Bucheli \& Leyva-Ortiz, 2016). In particular, students use Moodle to solve the online exams from anywhere (Jebari, Boussedra, \& Ettouhami, 2017; Shdiafat \& Obeidallah, 2019). In fact, this LMS immediately sends the feedback and results of the online exams (Al-Azawei, Baiee, \& Mohammed, 2019; ElSeoud, Ahmad, \& El-Sofany, 2009; Shdiafat \& Obeidallah, 2019). 
In courses of Engineering, Moodle increased the motivation of the students and academic performance (Aikina \& Bolsunovskaya, 2020). Even the use of the mobile devices in the educational field facilitated the access to the school contents and realization of the activities in Moodle (Aikina \& Bolsunovskaya, 2020). Likewise, the feedback of the activities in Moodle improved the assimilation of the knowledge in the field of engineering (Aikina \& Bolsunovskaya, 2020).

LMS allows that students view the information of the courses at any time (Aikina \& Bolsunovskaya, 2020; Jebari, Boussedra, \& Ettouhami, 2017; Veytia-Bucheli \& Leyva-Ortiz, 2016). In fact, the students of the Basic Programming course actively participated during the teaching-learning process through the realization of the online exams in Moodle (Al-Azawei, Baiee, \& Mohammed, 2019). Furthermore, this LMS allows the creation of the interactive spaces that facilitate the learning process about programming (Al-Azawei, Baiee, \& Mohammed, 2019).

In the course of the Information Systems Management, Moodle facilitated the personalization of the learning process through the review of the information and realization of the online exams (Jebari, Boussedra, \& Ettouhami, 2017). Likewise, this LMS improved the communication between the participants of the educational process through the use of the chat (Jebari, Boussedra, \& Ettouhami, 2017).

LMS allow the access to the virtual laboratories in order to facilitate the assimilation of knowledge (Ferreira \& Cardoso, 2005). For example, the students of Mechatronics developed their skills through the simulations in Moodle (Ferreira \& Cardoso, 2005). Likewise, this LMS facilitated the performance of the experiments through the virtual laboratories (Ferreira \& Cardoso, 2005).

In the course of Management System, Moodle facilitated the active role of the students through the consultation of the information, realization of the discussion forums and resolution of the online exams (ElSeoud, Ahmad, \& El-Sofany, 2009). In addition, this LMS facilitated the delivery of the assignments from anywhere and consultation of the grades at any time (El-Seoud, Ahmad, \& El-Sofany, 2009). Even Moodle increased the motivation of the students through the use of the technological applications (El-Seoud, Ahmad, \& El-Sofany, 2009).

Moodle transforms the teaching-learning process in the $21 \mathrm{st}$ century because this LMS facilitates the participation of the students during the teaching-learning process through the realization of the online exams (Al-Azawei, Baiee, \& Mohammed, 2019; Jebari, Boussedra, \& Ettouhami, 2017; Shdiafat \& Obeidallah, 2019), consultation of the contents (Aikina \& Bolsunovskaya, 2020; Vidrio-Talavera, Gómez-Zermeño, \& ZambranoIzquierdo, 2015), revision of the information (Jebari, Boussedra, \& Ettouhami, 2017), realization of the forums discussion (El-Seoud, Ahmad, \& El-Sofany, 2009; Jebari, Boussedra, \& Ettouhami, 2017; Veytia-Bucheli \& LeyvaOrtiz, 2016), use of the technological applications (Ferreira \& Cardoso, 2005) and delivery of the tasks (ElSeoud, Ahmad, \& El-Sofany, 2009; Veytia-Bucheli \& Leyva-Ortiz, 2016; Vidrio-Talavera, Gómez-Zermeño, \& Zambrano-Izquierdo, 2015).

Teachers use LMS to achieve the innovation in the educational field (Veytia-Bucheli \& Leyva-Ortiz, 2016). For example, the students of Education used Moodle to facilitate the assimilation of knowledge in the course of Literary Appreciation (Veytia-Bucheli \& Leyva-Ortiz, 2016). In fact, the incorporation of Moodle in the school activities increased the motivation of the students (Veytia-Bucheli \& Leyva-Ortiz, 2016). In the course of Literary Appreciation, Moodle allowed the participation of the forums, delivery of the assignments, download of the materials and realization of the online exams (Veytia-Bucheli \& Leyva-Ortiz, 2016).

In the course of Computer Science, Moodle facilitated the learning process and development of the technological skills by taking the online exams and delivering the tasks (Vidrio-Talavera, Gómez-Zermeño, \& Zambrano-Izquierdo, 2015). The results about the use of this LMS in the course of Informatics are the increase in the motivation of the students and improvement of the academic performance (Vidrio-Talavera, GómezZermeño, \& Zambrano-Izquierdo, 2015).

Finally, LMS such as Moodle allows the construction of the interactive spaces that facilitate the dissemination of the school contents, collaboration and communication between the participants of the educational process (Aikina \& Bolsunovskaya, 2020; Romero-Díaz, Sola-Martínez, \& Trujillo-Torres, 2015; SilvaOrdaz et al., 2016). Even the use of Moodle in the universities is increasing due to this LMS is easy to use (Aikina \& Bolsunovskaya, 2020; Shdiafat \& Obeidallah, 2019; Silva-Ordaz et al., 2016). 
Table 1. Questionnaire about the impact of Moodle in the educational field

\begin{tabular}{|c|c|c|c|c|c|c|}
\hline No. & Variable & Dimension & Question & Answer & $\mathrm{n}$ & $\%$ \\
\hline \multirow[t]{5}{*}{1} & \multirow[t]{5}{*}{ Teachers } & \multirow[t]{2}{*}{ Sex } & \multirow[t]{2}{*}{ 1. Indicate your sex } & Man & 36 & $51.43 \%$ \\
\hline & & & & Woman & 34 & $48.57 \%$ \\
\hline & & \multirow{3}{*}{$\begin{array}{l}\text { Maximum } \\
\text { degree of study }\end{array}$} & \multirow{3}{*}{$\begin{array}{l}\text { 2. Indicate your maximum } \\
\text { degree of study }\end{array}$} & Bachelor & 19 & $27.14 \%$ \\
\hline & & & & Master & 33 & $47.14 \%$ \\
\hline & & & & Doctorate & 18 & $25.71 \%$ \\
\hline \multirow[t]{16}{*}{2} & \multirow{16}{*}{$\begin{array}{l}\text { Technology in } \\
\text { the educational } \\
\text { field }\end{array}$} & \multirow[t]{4}{*}{ Moodle } & \multirow{4}{*}{$\begin{array}{l}\text { 3. Moodle facilitates the } \\
\text { organization of new school } \\
\text { activities }\end{array}$} & Too little (1) & 1 & $1.43 \%$ \\
\hline & & & & Little (2) & 14 & $20.00 \%$ \\
\hline & & & & Much (3) & 27 & $38.57 \%$ \\
\hline & & & & Too much (4) & 28 & $40.00 \%$ \\
\hline & & \multirow{4}{*}{$\begin{array}{l}\text { Participation and } \\
\text { communication }\end{array}$} & \multirow{4}{*}{$\begin{array}{l}\text { 4. The use of the technology } \\
\text { facilitates the participation } \\
\text { and communication during } \\
\text { the educational process }\end{array}$} & Too little (1) & 1 & $1.43 \%$ \\
\hline & & & & Little (2) & 7 & $10.00 \%$ \\
\hline & & & & Much (3) & 26 & $37.14 \%$ \\
\hline & & & & Too much (4) & 36 & $51.43 \%$ \\
\hline & & \multirow{4}{*}{$\begin{array}{l}\text { Activities inside } \\
\text { the classroom }\end{array}$} & \multirow{4}{*}{$\begin{array}{l}\text { 5. The performance of the } \\
\text { activities inside the } \\
\text { classroom through } \\
\text { technology is }\end{array}$} & Very rare (1) & 7 & $10.00 \%$ \\
\hline & & & & Rare (2) & 27 & $38.57 \%$ \\
\hline & & & & Frequent (3) & 21 & $30.00 \%$ \\
\hline & & & & Very frequent (4) & 15 & $21.43 \%$ \\
\hline & & \multirow{4}{*}{$\begin{array}{l}\text { Activities outside } \\
\text { the classroom }\end{array}$} & \multirow{4}{*}{$\begin{array}{l}\text { 6. The performance of the } \\
\text { activities outside the } \\
\text { classroom through } \\
\text { technology is }\end{array}$} & Very rare (1) & 3 & $4.29 \%$ \\
\hline & & & & Rare (2) & 18 & $25.71 \%$ \\
\hline & & & & Frequent (3) & 26 & $37.14 \%$ \\
\hline & & & & Very frequent (4) & 23 & $32.86 \%$ \\
\hline
\end{tabular}

\section{METHODOLOGY}

The objective of this quantitative research is to analyze the teachers' perceptions about the impact of Moodle in the educational field considering data science and machine learning.

\section{Participants}

The participants are 70 teachers (36 men and 34 women) from the National Autonomous University of Mexico (UNAM) who took the "Classroom of the Future 2020" Diploma. This diploma is financed by PAPIME projects (Program Support for Projects to Innovate and Improve the Education): PE106420, PE102920, PE106419, PE314819, PE306619 and PE104720 in order to improve the teaching-learning conditions considering the aspects of pedagogy and technology.

The research hypotheses about the impact of Moodle in the educational field are:

- Hypothesis $1(\mathrm{H} 1)$ : Moodle positively influences the participation and communication during the educational process

- Hypothesis $2(\mathrm{H} 2)$ : Moodle positively influences the performance of the activities inside the classroom

- Hypothesis $3(\mathrm{H} 3)$ : Moodle positively influences the performance of the activities outside the classroom

\section{Data Collection}

Table 1 shows the questionnaire used to collect the information on the impact of Moodle in the educational field.

\section{Data Analysis}

The Rapidminer tool allows building the predictive models through the decision tree technique and calculation of machine learning to evaluate the hypotheses about the impact of Moodle in the educational field.

In machine learning, the training section (50\%,60\% and $70 \%$ of the sample) allows calculating the linear regressions and evaluation section ( $50 \%, 40 \%$ and $30 \%$ of the sample) allows identifying the accuracy of these linear regressions. 
Table 2. Results of machine learning (linear regression)

\begin{tabular}{|c|c|c|c|c|}
\hline Hypothesis & Training & Linear regression & Conclusion & Squared error \\
\hline H1: Moodle $\rightarrow$ participation and & $50 \%$ & $y=0.420 x+2.755$ & Accepted: 0.420 & 0.391 \\
\hline communication during the & $60 \%$ & $y=0.454 x+2.558$ & Accepted: 0.454 & 0.364 \\
\hline educational process & $70 \%$ & $y=0.447 x+2.567$ & Accepted: 0.447 & 0.429 \\
\hline \multirow{3}{*}{$\begin{array}{l}\mathrm{H} 2: \text { Moodle } \rightarrow \text { performance of the } \\
\text { activities inside the classroom }\end{array}$} & $50 \%$ & $y=0.110 x+3.204$ & Accepted: 0.110 & 1.020 \\
\hline & $60 \%$ & $y=0.181 x+2.909$ & Accepted: 0.181 & 0.906 \\
\hline & $70 \%$ & $y=0.224 x+2.731$ & Accepted: 0.224 & 1.043 \\
\hline \multirow{3}{*}{$\begin{array}{l}\mathrm{H} 3: \text { Moodle } \rightarrow \text { performance of the } \\
\text { activities outside the classroom }\end{array}$} & $50 \%$ & $y=0.164 x+3.437$ & Accepted: 0.164 & 0.711 \\
\hline & $60 \%$ & $y=0.132 x+3.422$ & Accepted: 0.132 & 0.523 \\
\hline & $70 \%$ & $y=0.207 x+3.148$ & Accepted: 0.207 & 0.478 \\
\hline
\end{tabular}

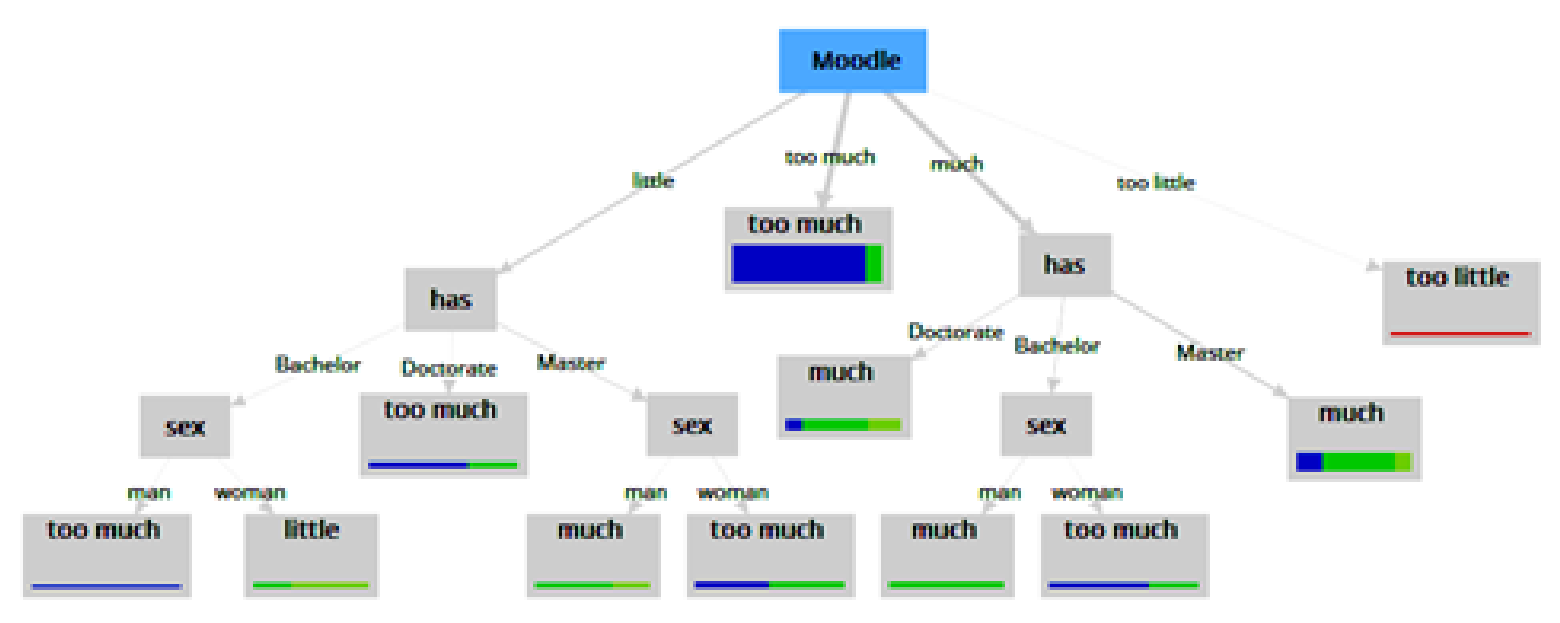

Figure 1. Predictive Model 1 on the impact of Moodle

Data science allows building the predictive models through the use of the Rapidminer tool. The information about the maximum degree of study and sex of the teachers, Moodle, participation and performance of the activities is used to build the predictive models through the decision tree technique.

\section{RESULTS}

Moodle facilitates too much $(n=28,40.00 \%)$, much $(n=27,38.57 \%)$, little $(n=14,20.00 \%)$ and too little ( $n$ $=1,1.43 \%$ ) the organization of new school activities (See Table 1). Likewise, the results of machine learning with $50 \%, 60 \%$ and $70 \%$ of training indicate that $\mathrm{H} 1, \mathrm{H} 2, \mathrm{H} 3$ are accepted (See Table 2).

\section{Participation and Communication during the Educational Process}

The use of the technology facilitates too much $(n=36,51.43 \%)$, much $(n=26,37.14 \%)$, little $(n=7,10.00 \%)$ and too little $(n=1,1.43 \%)$ the participation and communication during the educational process (See Table 1). The results of machine learning with $50 \%(0.420), 60 \%(0.454)$ and $70 \%(0.447)$ indicate that $\mathrm{H} 1$ is accepted (See Table 2). Therefore, Moodle positively influences the participation and communication during the educational process.

Figure 1 shows the Predictive Model 1 on the impact of Moodle in the educational field. For example, if the teacher considers that Moodle facilitates much the organization of new school activities and the maximum degree of study is Doctorate then the use of the technology facilitates much the participation and communication during the educational process. On the other hand, if the teacher considers that Moodle facilitates little the organization of new school activities, is a woman and the maximum degree of study is Bachelor then the use of the technology facilitates little the participation and communication during the educational process.

Table 3 shows the 11 conditions of the Predictive Model 1. For example, if the teacher considers that Moodle facilitates much the organization of new school activities and the maximum degree of study is Master 
Table 3. Conditions of the Predictive Model 1

\begin{tabular}{|c|c|c|c|c|}
\hline No. & $\begin{array}{c}\text { Moodle } \rightarrow \text { organization of new } \\
\text { school activities }\end{array}$ & Sex & Maximum degree of study & $\begin{array}{l}\text { Use of the technology } \rightarrow \\
\text { participation and communication }\end{array}$ \\
\hline 1 & Too much & - & - & Too much \\
\hline 2 & Much & - & Doctorate & Much \\
\hline 3 & Much & - & Master & Much \\
\hline 4 & Much & Man & Bachelor & Much \\
\hline 5 & Much & Woman & Bachelor & Too much \\
\hline 6 & Little & - & Doctorate & Too much \\
\hline 7 & Little & Man & Master & Much \\
\hline 8 & Little & Woman & Master & Too much \\
\hline 9 & Little & Man & Bachelor & Too much \\
\hline 10 & Little & Woman & Bachelor & Little \\
\hline 11 & Too little & - & - & Too little \\
\hline
\end{tabular}



Figure 2. Predictive Model 2 on the impact of Moodle

then the use of the technology facilitates much the pardticipation and communication during the educational process.

\section{Performance of the Activities inside the Classroom}

Table 1 indicates that the performance of the activities inside the classroom through technology is very frequent $(n=15,21.43 \%)$, frequent $(n=21,30.00 \%)$, rare $(n=27,38.57 \%)$ and very rare $(n=7,10.00 \%)$. The results of machine learning with $50 \%(0.110), 60 \%(0.181)$ and $70 \%(0.224)$ indicate that $\mathrm{H} 2$ is accepted (See Table 2). Therefore, Moodle positively influences the performance of the activities inside the classroom.

Figure 2 shows the Predictive Model 2 on the impact of Moodle in the educational field. For example, if the teacher considers that Moodle facilitates too much the organization of new school activities and the maximum degree of study is Doctorate then the performance of the activities inside the classroom through technology is frequent. On the other hand, if the teacher considers that Moodle facilitates little the organization of new school activities and the maximum degree of study is Doctorate then the performance of the activities inside the classroom through technology is frequent.

Table 4 shows the 8 conditions of the Predictive Model 2. For example, if the teacher considers that Moodle facilitates too much the organization of new school activities and the maximum degree of study is Bachelor then the performance of the activities inside the classroom through technology is very frequent. 
Table 4. Conditions of the Predictive Model 2

\begin{tabular}{|c|c|c|c|c|}
\hline No. & $\begin{array}{c}\text { Moodle } \rightarrow \text { organization of new } \\
\text { school activities }\end{array}$ & Sex & $\begin{array}{c}\text { Maximum degree of } \\
\text { study }\end{array}$ & $\begin{array}{c}\text { Moodle } \rightarrow \text { activities inside the } \\
\text { classroom }\end{array}$ \\
\hline 1 & Too much & - & Doctorate & Frequent \\
\hline 2 & Too much & - & Master & Frequent \\
\hline 3 & Too much & - & Bachelor & Very frequent \\
\hline 4 & Much & - & - & Rare \\
\hline 5 & Little & - & Doctorate & Frequent \\
\hline 6 & Little & - & Master & Very frequent \\
\hline 7 & Little & - & Bachelor & Rare \\
\hline 8 & Too little & - & - & Very rare \\
\hline
\end{tabular}



Figure 3. Predictive Model 3 on the impact of Moodle

Table 5. Conditions of the Predictive Model 3

\begin{tabular}{|c|c|c|c|c|}
\hline No. & $\begin{array}{c}\text { Moodle } \rightarrow \text { organization of new } \\
\text { school activities }\end{array}$ & Sex & $\begin{array}{c}\text { Maximum degree of } \\
\text { study }\end{array}$ & $\begin{array}{c}\text { Moodle } \rightarrow \text { activities outside the } \\
\text { classroom }\end{array}$ \\
\hline 1 & Too much & - & Doctorate & Very frequent \\
\hline 2 & Too much & - & Master & Frequent \\
\hline 3 & Too much & - & Bachelor & Very frequent \\
\hline 4 & Much & - & - & Frequent \\
\hline 5 & Little & - & Doctorate & Rare \\
\hline 6 & Little & - & Master & Very frequent \\
\hline 7 & Little & - & Bachelor & Very frequent \\
\hline 8 & Too little & - & - & Very rare \\
\hline
\end{tabular}

\section{Performance of the Activities outside the Classroom}

Table 1 indicates that the performance of the activities outside the classroom through technology is very frequent $(n=23,32.86 \%)$, frequent $(n=26,37.14 \%)$, rare $(n=18,25.71 \%)$ and very rare $(n=3,4.29 \%)$. Likewise, the results of machine learning with $50 \%(0.164), 60 \%(0.132)$ and $70 \%(0.207)$ indicate that $\mathrm{H} 3$ is accepted (See Table 2). Therefore, Moodle positively influences the performance of the activities outside the classroom.

Figure 3 shows the Predictive Model 3 on the impact of Moodle in the educational field. For example, if the teacher considers that Moodle facilitates too much the organization of new school activities and the maximum degree of study is Doctorate then the performance of the activities outside the classroom through technology is very frequent. On the other hand, if the teacher considers that Moodle facilitates little the organization of new school activities and the maximum degree of study is Doctorate then the performance of the activities outside the classroom through technology is rare.

Table 5 shows the 8 conditions of the Predictive Model 3. For example, if the teacher considers that Moodle facilitates too much the organization of new school activities and the maximum degree of study is Master then the performance of the activities outside the classroom through technology is frequent.

\section{DISCUSSION}

This research shares the ideas of various authors (e.g., Aikina \& Bolsunovskaya, 2020; Al-Azawei, Baiee, \& Mohammed, 2019; Jebari, Boussedra, \& Ettouhami, 2017) about the importance of using Moodle to transform 
the teaching-learning process. Most of the teachers $(n=28,40.00 \%)$ think that Moodle facilitates too much the organization of new school activities.

\section{Participation and Communication during the Educational Process}

Moodle improved the communication (Jebari, Boussedra, \& Ettouhami, 2017) and participation (Al-Azawei, Baiee, \& Mohammed, 2019; Shdiafat \& Obeidallah, 2019) during the educational process.

Most of the teachers $(n=36,51.43 \%$ ) think that the use of the technology facilitates too much the participation and communication during the educational process. Likewise, the results of machine learning on $\mathrm{H} 1$ are higher than $\mathbf{0 . 4 1 9}$, therefore, Moodle positively influences the participation and communication during the educational process. Data science identifies 11 conditions of the Predictive Model 1. In fact, the decision tree technique establishes the conditions on the use of this LMS considering the characteristics of the teachers (sex and maximum degree of study). For example, if the teacher considers that Moodle facilitates much the organization of new school activities and the maximum degree of study is Doctorate then the use of the technology facilitates much the participation and communication during the educational process.

\section{Performance of the Activities inside the Classroom}

Veytia-Bucheli and Leyva-Ortiz (2016) explain that the use of Moodle in face-to-face sessions and outside the classroom allows creating new learning spaces. Most of the teachers $(n=27,38.57 \%)$ think that the performance of the activities inside the classroom through technology is rare. Likewise, the results of machine learning on $\mathrm{H} 2$ are greater than 0.100 , therefore, Moodle positively influences the performance of the activities inside the classroom. Data science identifies 8 conditions of Predictive Model 2 through the decision tree technique. For example, if the teacher considers that Moodle facilitates too much the organization of new school activities and the maximum degree of study is Doctorate then the performance of the activities inside the classroom through technology is frequent.

\section{Performance of the Activities outside the Classroom}

Aikina and Bolsunovskaya (2020) mention that Moodle allows the organization and realization of various activities such as the consultation of the multimedia resources and delivery of the tasks at any time.

Most of the teachers ( $n=26,37.14 \%$ ) think that the performance of the activities outside the classroom through technology is frequent. Likewise, the results of machine learning on $\mathrm{H} 3$ are greater than 0.130 , therefore, Moodle positively influences the performance of the activities outside the classroom. Data science identifies 8 conditions of the Predictive Model 3 through the decision tree technique. For example, if the teacher considers that Moodle facilitates too much the organization of new school activities and the maximum degree of study is Doctorate then the performance of the activities outside the classroom through technology is very frequent.

\section{CONCLUSION}

Teachers use technology to facilitate the learning process, create new educational spaces and improve the organization of the courses. For example, Moodle positively influences the participation and communication during the educational process. In fact, this LMS allows the realization of discussion forums and delivery of tasks from anywhere.

Technological advances allow innovating the educational process, improving the learning conditions and facilitating the interaction between the teachers, students and school contents. In particular, Moodle positively influences the performance of the activities inside and outside the classroom. Teachers use this LMS to promote the active participation of students by consulting the information and taking the exams online at any time.

The limitations of this research are the analysis about the impact of Moodle in the educational field and perceptions of the teachers in a university. Therefore, future research may analyze the impact of LMS such as Canvas, Schoology and Blackboard at various universities.

This research recommends the incorporation of Moodle in the educational field to create virtual learning spaces that increase the motivation and satisfaction of the students and facilitate the performance of active 
activities at any time and from anywhere. Also, the implications of this research allow affirming that teachers have the opportunity to create, organize and carry out various creative and active activities through this LMS.

Teachers are changing the organization of the school activities, communication, interaction and behavior of the students through the use of the technology. For example, Moodle facilitates the participation and communication during the educational process and performance of the activities inside and outside the classroom.

\section{ACKNOWLEDGEMENTS}

This work was supported by UNAM-DGAPA-PAPIME (Project Support Program to Innovate and Improve Education): PE106420 (El Aula del Futuro del CCH Vallejo), PE102920 (El Aula del Futuro del Instituto de Geofísica), PE106419 (El Aula del Futuro: de la Escuela Nacional Preparatoria 7), PE314819 (SUAyED de la Facultad de Filosofía y Letras), PE306619 (El Aula del Futuro: SUA de la Facultad de Psicología) y PE104720 (EI Aula del Futuro del Instituto de Geología). Likewise, the support provided by the National School of Social Work and Faculty of Arts and Design is appreciated. The participation of the following academics is appreciated: PhD Clara Alvarado Zamorano, PhD Gustavo De la Cruz Martínez, Master Jesús Ramírez Ortega, Master Ricardo Castañeda Martínez and Master Antonio M. Garcés Madrigal.

\section{REFERENCES}

Aikina, T. Y., \& Bolsunovskaya, L. M. (2020). Moodle-Based Learning: Motivating and Demotivating Factors. International Journal of Emerging Technologies in Learning, 15(2), 239-248. https://doi.org/10.3991/ijet.v15i02.11297

Al-Azawei, A., Baiee, W. R., \& Mohammed, M. A. (2019). Learners' Experience Towards e-Assessment Tools: A Comparative Study on Virtual Reality and Moodle Quiz. International Journal of Emerging Technologies in Learning, 14(5), 34-49. https://doi.org/10.3991/ijet.v14i05.9998

Cobanoglu, A. A. (2018). Student teachers' satisfaction for blended learning via Edmodo learning management $\begin{array}{lllll}\text { system. Behaviour \& Information } & \text { Technology, } & 37(2), & \end{array}$ https://doi.org/10.1080/0144929X.2017.1417481

Dreamson, N., Thomas, G., Hong, A. L., \& Kim, S. (2018). The perceptual gaps in using a learning management system: Indigenous cultural perspectives. Technology, Pedagogy and Education, 27(4), 431-444. https://doi.org/10.1080/1475939X.2018.1490665

El-Seoud, S. A., Ahmad, A. M., \& El-Sofany, H. F. (2009). Mobile Learning Platform Connected to Moodle using J2ME. International Journal of Interactive Mobile Technologies, 3(2), 46-54.

Ferreira, J. M., \& Cardoso, A. M. (2005). A Moodle extension to book online labs. International Journal of Online and Biomedical Engineering, 1(2), 1-4.

González, S. M. G., Pintor-Chávez, M. M., \& Gómez-Zermeño, M. G. (2016). Indicators for the evaluation of the level of satisfaction of the use of blackboard educational platform. Campus Virtuales, 5(1), 36-47.

Gutman, M. (2017). Facilitating pre-service teachers to develop Regulation of Cognition with Learning Management System. Educational Media International, 54(3), 199-214. https://doi.org/10.1080/09523987.2017.1385164

Horvat, A., Dobrota, M., Krsmanovic, M., \& Cudanov, M. (2015). Student perception of Moodle learning management system: a satisfaction and significance analysis. Interactive Learning Environments, 23(4), 515-527. https://doi.org/10.1080/10494820.2013.788033

Islam, A. K. (2015). The moderation effect of user-type (educators vs. students) in learning management system continuance. Behaviour \& Information Technology, 34(12), 1160-1170. https://doi.org/10.1080/0144929X.2015.1004651

Jebari, K., Boussedra, F., \& Ettouhami, A. (2017). Teaching Information Systems Management' with Moodle. International Journal of Emerging Technologies in Learning, 12(4), 4-16. https://doi.org/10.3991/ijet.v12i04.6183

Kyzy, Z. N., Ismailova, R., \& Dundar, H. (2018). Learning management system implementation: a case study in the Kyrgyz Republic. Interactive Learning Environments, 26(8), 1010-1022. https://doi.org/10.1080/10494820.2018.1427115 
Kotama, N. D., Saputra, K. O., \& Linawati, L. (2019). Proposed Model of Multiplayer Matching Game Plugins Using Websocket in Moodle. International Journal of Emerging Technologies in Learning, 14(11), $194-201$. https://doi.org/10.3991/ijet.v14i11.10190

Limongelli, C., Lombardi, M., Marani, A., Sciarrone, F., \& Temperini, M. (2016). A recommendation module to help teachers build courses through the Moodle Learning Management System. New Review of Hypermedia and Multimedia, 22(1), 58-82. https://doi.org/10.1080/13614568.2015.1077277

Mafuna, L., \& Wadesango, N. (2016). Exploring Lecturers' Acceptance Level of Learning Management System (LMS) at Applying the Extended Technology Acceptance Model (TAM). Journal of Social Sciences, 48(1), 6370. https://doi.org/10.1080/09718923.2016.11893571

Oskouei, R. J., \& Kor, N. M. (2017). Proposing a Novel Adaptive Learning Management System: An Application of Behavior Mining \& Intelligent Agents. Intelligent Automation \& Soft Computing, 23(2), 199-205. https://doi.org/10.1080/10798587.2016.1186429

Rehatschek, H., Holzl, G., \& Fladischer, M. (2011). The Set-Up and Implementation of Fully Virtualized Lessons with an Automated Workflow Utilizing VMC/Moodle at the Medical University of Graz. International Journal of Emerging Technologies in Learning, 6(4), 47-51. http://dx.doi.org/10.3991/ijet.v6i4.1784

Romero-Díaz, J. J., Sola-Martínez, T., \& Trujillo-Torres, J. M. (2015). Instructional Capabilities of Moodle Tools for Production of Courses and Educational Materials. Digital Education Review, 28, 59-76.

Salas-Rueda, R. A. (2020). Impact of the WampServer application in Blended learning considering data science, machine learning, and neural networks. E-Learning and Digital Media, 17(3), 199-217. https://doi.org/10.1177/2042753020901730

Salas-Rueda, R. A. (2019). Construction and evaluation of a web application for the educational process on Normal Distribution considering the science of data and machine learning. Research in Learning Technology, 27, 1-24. https://doi.org/10.25304/rlt.v27.2085

Salas-Rueda, R. A., \& Lugo-García, J. L. (2019). Impact of the flipped classroom during the higher education process on the derivatives considering the science of data and learning machine. EDMETIC, Revista de Educación Mediática y TIC, 8(1), 147-170. https://doi.org/10.21071/edmetic.v8i1.9542

Salas-Rueda, R. A., Salas-Rueda, E. P., \& Salas-Rueda, R. D. (2020). Analysis and design of the web game on descriptive statistics through the ADDIE model, data science and machine learning. International Journal of Education in Mathematics, Science and Technology, 8(3), 245-260. https://doi.org/10.46328/ijemst.v8i3.759

Shah, M., \& Cheng, M. (2019). Exploring factors impacting student engagement in open access courses. Open Learning: The Journal of Open, Distance and e-Learning, 34(2), 187-202. https://doi.org/10.1080/02680513.2018.1508337

Shdiafat, A., \& Obeidallah, R. (2019). Quiz Tool Within Moodle and Blackboard Mobile Applications. International Journal of Interactive Mobile Technologies, 13(8), 32-41. https://doi.org/10.3991/ijim.v13i08.10552

Silva-Ordaz, M., García-Ramírez, T., Guzmán-Flores, T., \& Chaparro-Ramírez, R. (2016). Study of Moodle's tools to develop 21st Century skills. Campus Virtuales, 5(2), 58-69.

Then, M., Wallenborn, B., Ianniello, B. R., Vu, D. V., Fuchs, M., \& Hemmje, M. (2016). Innovative Authoring Tools for Online-Courses with Assignments. International Journal of Emerging Technologies in Learning, 11(2), 1222. https://doi.org/10.3991/ijet.v11i02.5108

Tumbleson, B. E. (2016). Collaborating in Research: Embedded Librarianship in the Learning Management System. The Reference Librarian, 57(3), 224-234. https://doi.org/10.1080/02763877.2015.1134376

Veytia-Bucheli, M. G., \& Leyva-Ortiz, J. A. (2016). Teaching literature with Moodle in the Bachelor of Education. Apertura, 9(1), 64-79.

Vidrio-Talavera, P. D., Gómez-Zermeño, M. G., \& Zambrano-Izquierdo, D. (2015). Didactic assessment of Moodle platform in high school. Apertura, 7(1), 1-14.

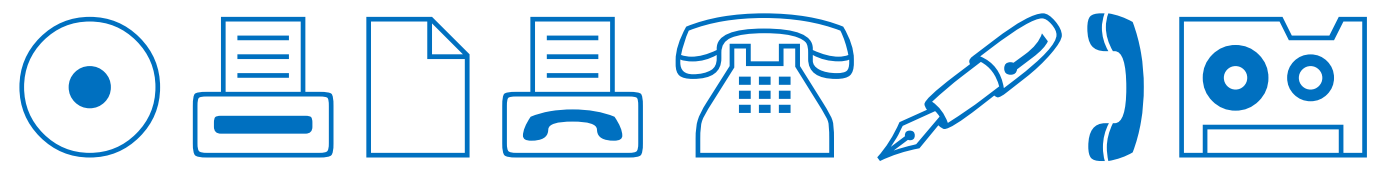

